\title{
Error analysis of prospective mathematics teachers in solving of applying radian measurement problem in trigonometry courses
}

\author{
Yayan Eryk Setiawan', Surahmat1 \\ ${ }^{1}$ Universitas Islam Malang, Indonesia \\ $\triangle$ yayaneryksetiawan@unisma.ac.id*
}

\author{
Article Information \\ Submitted Sept 11, 2021 \\ Revised Sept 27, 2021 \\ Accepted Oct 03, 2021
}

Keywords

Applying the Radian

Measurements;

Factual Errors;

Misconceptions;

Trigonometry.

\begin{abstract}
This research aims to describe the mistakes of the prospective teachers in solving the application of radian measurement problems and their causes. This type of research is qualitative descriptive research with a case study approach. The types of data collection in this research consisted of the results of the subject's work and transcripts of interviews with research subjects. By following the type of data, this research instrument consists of one question about the problem of applying radian measurement and interview guidelines developed by the researchers. Data analysis of the subject's work is carried out by classifying the types of errors to know the types of errors that arise in solving the problem of applying the radian measurements. While the transcript analysis of the interview results was carried out by coding the words to determine the factors causing the errors that appeared. The results of the research indicate that the error in solving the problem of applying the radian measurement are misconceptions and factual errors. This misconception is generally caused by intuitive thinking, while this factual error is generally caused by not paying careful attention to the information in the question. The solution to these errors is to analyze the elements of the circle that are interconnected in solving the problem of applying the radian measurements and to be careful in writing the information that is known in the question.
\end{abstract}

\section{INTRODUCTION}

Trigonometry is a branch of mathematics that specifically discusses trigonometric functions (Lial et al., 2016). At some universities, trigonometry is taught through trigonometry courses. Students who are required to take this trigonometry course are students of the mathematics education study program. Because trigonometry is also taught at the senior high school. Some researchers also say that this trigonometry material is important to be taught to students (Nabie et al., 2018; Nejad, 2016; Siyepu, 2015; Tuna, 2013a, 2013b). Therefore, prospective mathematics teachers are expected to be able to master the concepts contained in this trigonometry material.

One of the materials studied in the trigonometry course is the application of radian measurements. The material for the application of radian measurements consists of determining the length of the arc of a circle and the area of the circle (Lial et al., 2016). An example of the problem of applying radian measurements involving the arc length of a circle can be seen in Figure 2 in the research method. The problem in Figure 2 can be solved by analyzing the relationship of known elements between the small gear and the large gear, where the relationship is that the arc length of the large gear is equal to the arc length of the small gear, and the linear speed between the small and large gears is the same. By using the similarity of arc length or linear velocity, the problem in Figure 1 can be solved. However, if students do not analyze the relationship between the two gears, then students will get stuck in the problem-solving error in Figure 2. For example, using a comparison of the length of the radius of a small gear with the length of the radius of a large gear. Therefore, in solving the problem of applying this radian 
measurement, analytical thinking is needed. It is based on the results of research showing that trigonometry courses involve more analytical thinking (Nabie et al., 2018).

The results of the preliminary study showed that of the 82 prospective teachers of the mathematics education study program, 57 prospective teachers answered correctly, and 25 prospective teachers answered incorrectly in solving the problem of applying radian measurements. It means that $30 \%$ of students fail to solve the problem of applying the radian measurement. Student errors in solving the problem of applying radian measurements are important for further analysis. This is because, through error analysis, student misunderstandings can be identified. By knowing student misunderstandings, students can correct their misunderstandings in learning material (Schleppenbach et al., 2007; Setiawan, 2020b, 2021c). Meanwhile, lecturers or teachers can improve their learning (Baroody et al., 2007; Setiawan, 2021a) by reducing things that can cause student errors or student misunderstandings. In addition, this error will have an impact on other related material errors (Safriani et al., 2019). Therefore, it is important to analyze student errors in solving the problem of applying radian measurements.

The research on prospective teachers' errors in solving trigonometric problems has been carried out previously by several researchers, namely (Gür, 2009; Hidayat \& Aripin, 2020; Imelda, 2018; Jaelani, 2017; Nabie et al., 2018; Setiawan, 2021c, 2021a, 2021b, 2021d). The research results of Gür (2009) show that students still experience errors in the form of using inappropriate equations. The research results of Hidayat dan Aripin (2020) show that students experience errors in facts, concepts, procedures, and metacognition. The research results of Imelda (2018) show that students still experience errors due to a lack of mastery of concepts. The research results of Jaelani (2017) show that students still experience errors in the form of swapping formulas. The research results of Nabie et al. (2018) show that students find trigonometry difficult and abstract. The results also showed that students experienced arithmetic errors in determining the integral of trigonometric functions (Christinove \& Mampouw, 2019). The results of the latest research also show that students still experience misconception, arithmetic errors, principle errors, and factual errors in determining the value of trigonometric functions of special angles, quadrant angles, non-acute angles, and triangular problems (Setiawan, 2021a, 2021d, 2021b, 2021c). The results of other research also show that students experience conceptual and principle errors in solving angular velocity problems (Setiawan, 2021e). However, this previous research did not discuss student errors in solving the problem of applying radian measurements. Therefore, research is still needed on the analysis of student errors in solving the problem of applying radian measurements. In this regard, this research aims to describe the errors of prospective teachers in solving the problem of applying radian measurements and the factors that cause them.

The results of this research will be useful theoretically, namely developing a theory of student errors in solving mathematical problems, especially in the problem of applying radian measurements. In addition, the practical benefit of the results of this research can be used by teachers or lecturers to improve their learning in conveying material on the application of radian measurements by emphasizing on students to avoid errors in problem-solving of applying radian measurements. 


\section{METHODS}

By the objectives of this research, this research method uses qualitative descriptive research with a case study approach to 4 prospective teachers of the mathematics education study program at one of the universities in Malang city who experienced errors in solving the problem of applying radian measurements. This research consists of three stages which can be seen in Figure 1.

The first stage is the selection of research subjects. The procedure for selecting the research subjects consisted of three steps. The first step is to ask 82 prospective teachers to complete the Mid Semester Examination questions, one of which is the problem of applying the radian measurement. The second step is to correct the answers of 82 prospective teachers based on right and wrong answers. There are 57 prospective teachers answered correctly and 25 prospective teachers answered incorrectly in solving the problem of applying radian measurements, 7 did not answer and 18 answered incorrectly. The third step is to classify the answers of 18 prospective teachers based on the type of error, to obtain 4 characteristics of student errors. From these 4 error characteristics, one student was selected as a research subject for further analysis, so that the total subjects of this research are 4 prospective teachers.

The second stage is data collection. The data collected in this research consisted of the results of the subject's work and transcripts of the results of interviews with the subject. The procedure for the data collection on the results of the subject's work is carried out by the steps for collecting the subject. From the steps of collecting the subject, 4 subjects were obtained, then from these 4 subjects, the results of the subject's work were obtained. The procedure for collecting interview transcripts was carried out in two steps. The first step is to conduct interviews with research subjects. Interviews were conducted via WhatsApp and the results were recorded. The second step is to transcribe the results of the interviews verbatim, to obtain data in the form of transcripts of the interviews results with research subjects. 


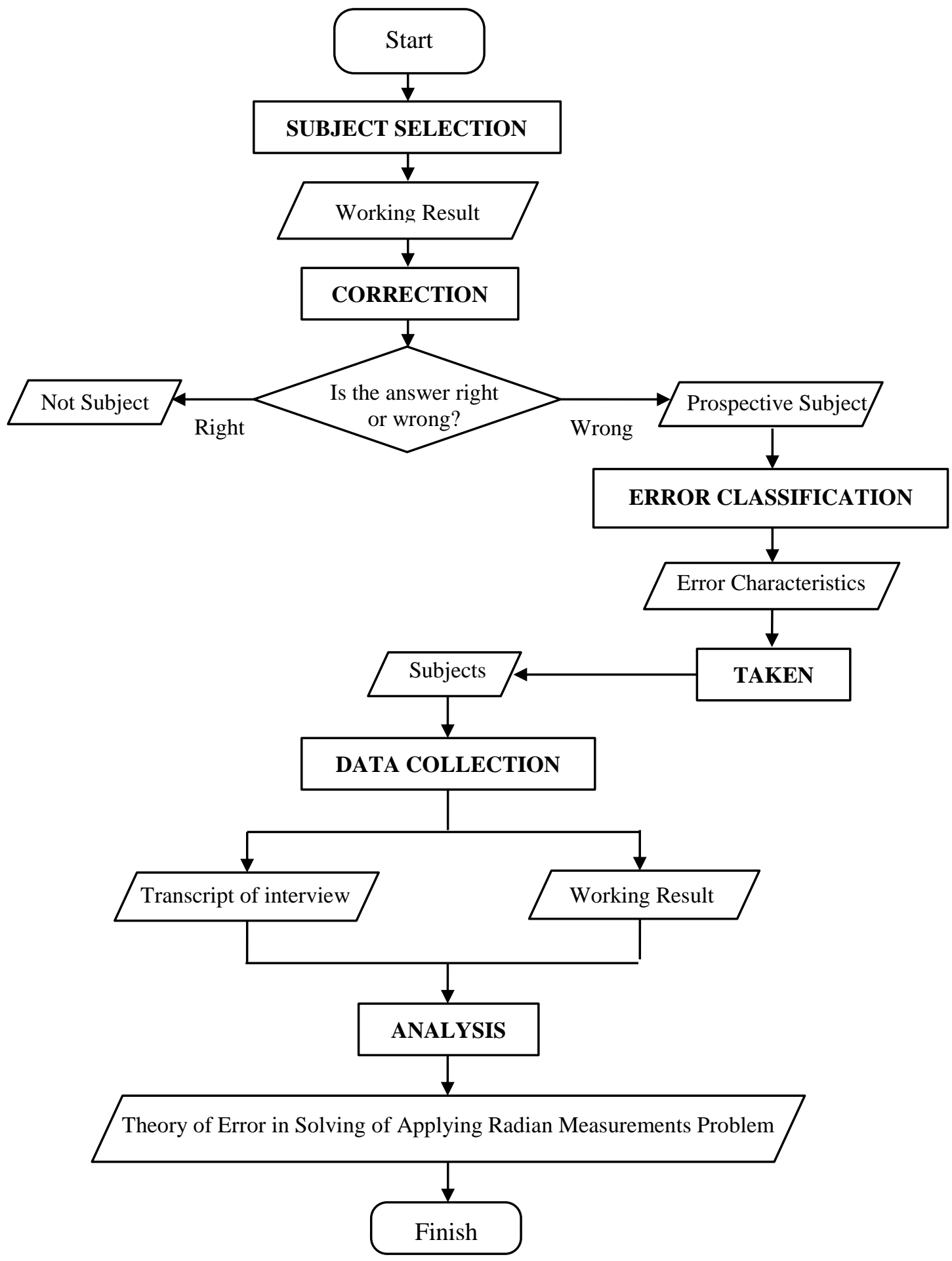

Figure 1. Research Stages

By the data to be collected in this research, the research instrument consists of questions about the problem of measuring radians (see Figure 2) and interview guidelines developed by the researcher. In Figure 2, it can be seen that to solve the problem, an understanding of the information contained in the problem is needed. If students do not understand the information contained in the problem, then students will be trapped into factual errors. Fact errors are errors in identifying known information (Muthukrishnan et al., 2019; Oktaviani, 2017; Setiawan, 2020c). This instrument also involves calculations. If the student is wrong in determining the result of the arithmetic operation, then the student has a calculation error. The concept used to complete the instrument is the concept of arc length, the linear velocity of the two circles, or the 
inverse ratio of values. If students do not pay attention to these two concepts, then students experience misconceptions. A misconception is defined as an error in understanding a concept (Setiawan, 2020c). So, this research instrument is valid to be used to find out student errors in solving the problem of applying radian measurements.

It is known that two gears are adjusted so that the smaller gear drives the larger gear, as shown in the following figure.

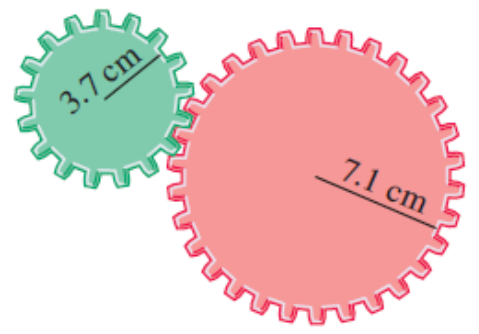

If the smaller gear rotates at an angle of $240^{\circ}$, how many degrees will the larger gear rotate?

Source: adaptation of (Lial et al., 2016)

Figure 2. Research Instruments

The third stage is data analysis. The analysis of the results of the subject's work was carried out by classifying the subject's errors based on a misconception, miscalculation, and factual errors (see Table 1). The selection of concept errors, calculation errors, and factual errors is based on the materials and instruments used in this research. Where, the materials and research instruments used can be completed by understanding the concepts of arc length, linear velocity, and the ratio of reverse values. In addition, the completion of the instrument also involves arithmetic operations and facts about the information contained in the research instrument. Thus, error analysis based on a misconception, miscalculation, and factual error has been in accordance with research materials and instruments regarding the application of radian measurement.

Table 1. Classification of Student Errors

\begin{tabular}{|c|c|c|}
\hline No & Types of Errors & Indicators \\
\hline 1 & Misconception & $\begin{array}{l}\text { Errors in understanding the concepts used to solve the problem of } \\
\text { applying radian measurements. }\end{array}$ \\
\hline 2 & Miscalculation & Errors in determining the result of arithmetic operations. \\
\hline 3 & Factual Error & Errors in understanding the questions. \\
\hline & & Errors in identifying the information contained in the problem. \\
\hline
\end{tabular}

Data analysis in the form of transcripts of interviews results was carried out by coding words that indicated the error factors made by the subject. Through this coding analysis, it is expected that the misunderstanding of the subject who experienced the error can be identified. Thus, through analysis of work results and transcripts of interviews results, student errors in solving problems of applying the radian measurements can be identified properly.

\section{RESULTS AND DISCUSSION}

The results showed that of 82 prospective teachers, 25 answered incorrectly in solving the problem of applying the radian measurements. Of the 25 prospective teachers who answered 
incorrectly, 7 did not answer and 18 answered incorrectly. The results of the error classification of 18 prospective teachers who answered incorrectly can be seen in Table 2.

Table 2. Results of Error Classification in Solving Radian Measurement Problems

\begin{tabular}{|c|c|c|c|c|}
\hline No & Types of Errors & Indicators & $\begin{array}{c}\text { Errors in Solving Problems of } \\
\text { Applying Radian Measurement }\end{array}$ & $\begin{array}{l}\text { Number of } \\
\text { Students }\end{array}$ \\
\hline \multirow[t]{3}{*}{1} & Misconception & $\begin{array}{l}\text { Errors in understanding } \\
\text { the concepts used to }\end{array}$ & $\begin{array}{l}\text { Error using comparison to determine } \\
\text { the size of the angle in the question. }\end{array}$ & 10 \\
\hline & & $\begin{array}{l}\text { solve the problem of } \\
\text { applying radian } \\
\text { measurements. }\end{array}$ & $\begin{array}{l}\text { Misunderstood the formula for } \\
\text { determining the arc length (i.e., the } \\
\text { angle value is assumed to be } 360 \\
\text { degrees). }\end{array}$ & 2 \\
\hline & & & Error using area comparison & 1 \\
\hline 2 & Miscalculation & $\begin{array}{l}\text { Errors in determining the } \\
\text { result of arithmetic } \\
\text { operations. }\end{array}$ & - & - \\
\hline 3 & Factual Error & $\begin{array}{l}\text { Errors in identifying the } \\
\text { information contained in } \\
\text { the problem. }\end{array}$ & $\begin{array}{l}\text { Known writing errors, namely the } \\
\text { measure of the angle }\end{array}$ & 5 \\
\hline
\end{tabular}

In Table 2, it can be seen that of the 18 students who experienced errors in solving the problem of applying the radian measurement, $72 \%$ experienced misconception and $28 \%$ experienced factual errors. There are no students who have miscalculated. From each of these error characteristics, 1 student was taken as the research subject. So that the total subjects of this study were 4 students.

\section{Misconception}

The first misconception experienced by students in solving the problem of applying the radian measurements is an error using comparisons. 10 students used comparisons to solve the problem of applying the radian measurements. From the 10 students, 1 student was selected as the first subject (S1) of this research. The results of this first subject's work can be seen in Figure 3.

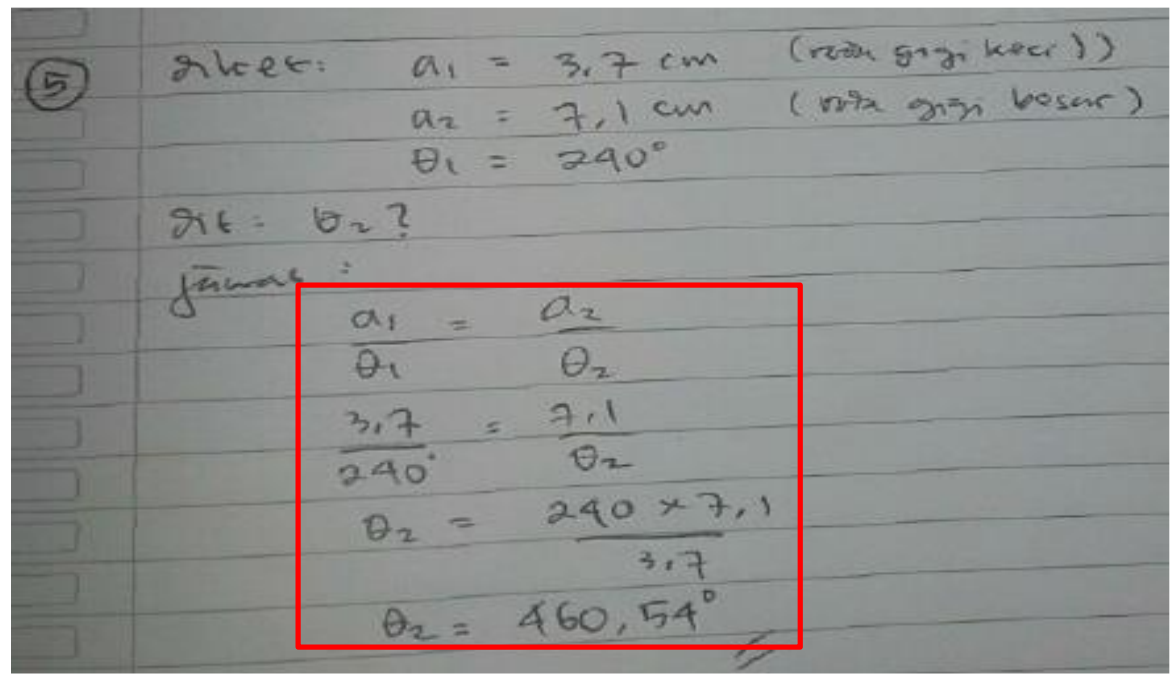

Figure 3. Errors Using Comparison

From Figure 3, it can be seen that the subject used an inappropriate comparison. From the unsuitable comparison, the equation $\theta_{2} \times 3.7=240^{\circ} \times 7.1$, then the value of $\theta_{2}=460.54^{0}$ is 
obtained. If we look at the problem, it is known that the radius of the small gear is 3.7 with a center of $240^{\circ}$ and it is known that the radius of the large gear is 7.1 and the central angle of the large gear is asked. If further analyzed, it will be obtained that the angle formed by the large gear is smaller than the small gear, so the appropriate comparison is the inverse ratio. However, the subject used an equivalent ratio which in the end was wrong in determining the value of the center angle of the large gear. Factors causing this error can be seen from the following interview excerpts.

$R \quad: \quad$ Please, could you explain the method you use?

S1 : I used the equivalent ratio formula, to find the center angle of the large gear. Let's say $a_{1}$ is the small gear radius, and $a_{2}$ is the big gear radius. Then I write $a_{1} / \theta_{1}$ equals $a_{2} / \theta_{2}$, then I substitute the values, which is $3.7 / 240^{\circ}$ equals $7.1 / Q_{2}$. Then $\theta_{2}$ gets 240 multiplied by 7,1 divided by 3.7 , and the result of $\theta_{2}$ is $460.54^{\circ}$.

$R \quad: \quad$ Why did you use this comparison?

S1 : My completion time as long as I use the value comparison, sir, I think it's like that.

From the interview excerpts, it can be seen that the factors causing the subject to use an inappropriate comparison are because the subject directly uses an equivalent comparison, without analyzing what comparison is appropriate to solve the problem. So, the factor causing this error, in general, is intuitive thinking which is only based on the subject's perception when facing the problem.

The second misconception is a misunderstanding of the value of the $\theta$ angle when students use the arc length formula, namely $s=r \theta$, where the subject thinks that the value of $\theta=360^{0}$ or $\theta=2 \pi$. 2 students experienced this error. Of these 2 students, 1 student was selected as the second subject of this research. The results of the work of the second subject (S2) can be seen in Figure 4.

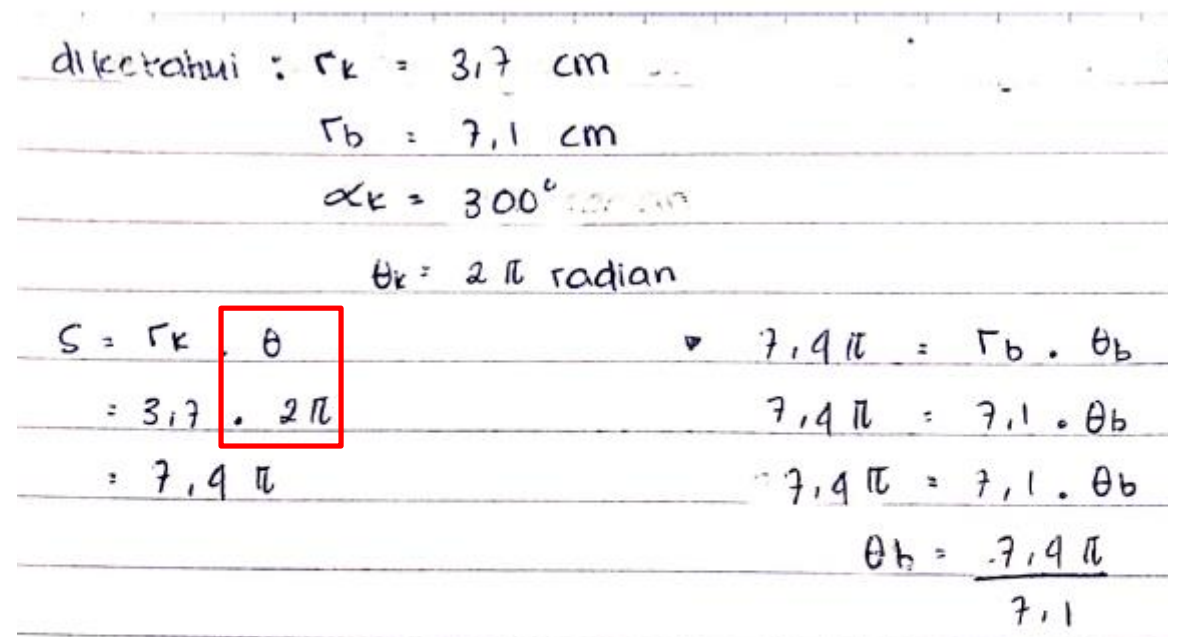

Figure 4. Misconceptions About the Value of the $\theta$ Angle.

From Figure 4 it can be seen that the subject was correct in writing the arc length formula, namely $s=r \theta$. However, the subject substituted the wrong value for $\theta$, namely $\theta=2 \pi$. Even though the known $\theta$ value is $\theta=300^{\circ}$, then the result is that the subject has an error in solving the problem of applying the quadrant angle. The factors causing this error can be identified from the following interview transcript. 
$R \quad$ : Why did you substitute the value of $\theta=2 \pi$ in the formula $s=r \theta$ ?

$S 2$ : Yes sir, because the value of $\theta$ is $2 \pi$ or $360^{\circ}$, while $\alpha$ angle is $\alpha=300^{\circ}$

From the interview transcript, it can be seen that the factor causing the error in substituting the value of $\theta$ from the arc length formula $s=r \theta$ is the subject's misunderstanding of the value, where the subject has a wrong understanding that $\theta=2 \pi$ or $\theta=360^{\circ}$, while the angle known as $\alpha=300^{\circ}$. Therefore, it is important to provide an understanding of the angle in the arc length formula $s=r \theta$, where $\theta$ is the angle in the circle that is in front of the arc length $s$.

The third misconception is the error in applying the comparison in using the area of a circle. There is 1 student who experienced this error. Then, this 1 student was chosen as the third subject (S3) in this research. The results of the work of the third subject can be seen in Figure 5. From Figure 5, it can be seen that the subject compares something that has nothing to do, namely the size of the central angle with the area of the circle. The central angle in the context of this problem is not affected by the area of the circle. However, in this context, the central angle is affected by the arc length. Therefore, the subject experienced an error in answering the question by using a comparison between the area of the circle and the size of the central angle. The factors causing this error can be seen from the following transcript of the interview results.

\section{$R \quad$ : Please, could you explain the method you use? \\ $S 3$ : I took material from an 8th-grade junior high school book, where it explained the relationship between the angles of the center of the circle and the area of the circle. Why I took it, because every circle, small or large, has the same value of pi.}

From the transcript of the interview, it can be seen that the factor causing the subject to compare the central angle with the area of a circle is a misunderstanding in understanding the relationship between the central angle and the area of the circle. Where the subject's misunderstanding was to say that the central angle always has a relationship with the area of the circle because every circle has the same value of pi. The subject does not analyze further the parts of the circle of the elements of the circle that have a relationship. Therefore, it is important to teach students about the parts or elements of a circle that have a relationship. So that they can answer the questions correctly.

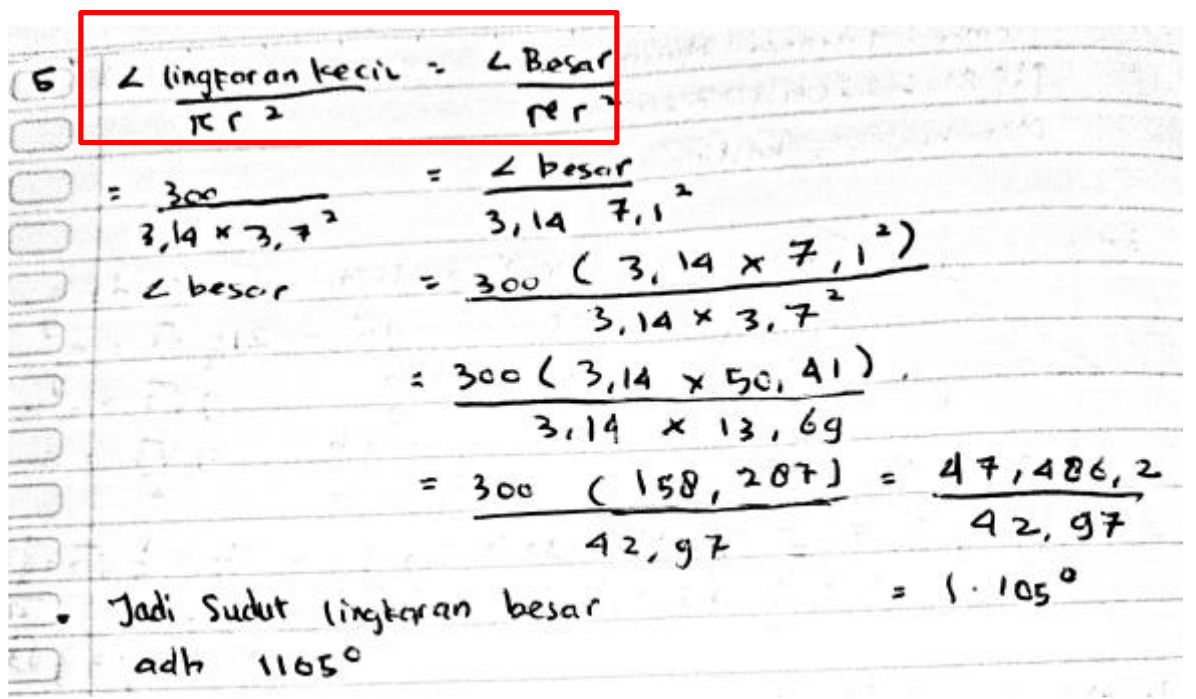

Figure 5. Error in Applying Comparison of Center Angle to Area of a Circle. 


\section{Factual Error}

Factual errors that arise in this research are errors in rewriting the information contained in the questions. 5 students experience this error. From these 5 students, 1 student was selected as the fourth subject (S4) of this research. The results of the work of the fourth subject can be seen in Figure 6. From Figure 6, it can be seen that the subject experienced an error in writing the information that was known in the problem, where the subject's error was writing down the known angle size, namely $300^{\circ}$. Whereas, what is known though is $240^{\circ}$. Factors causing this error can be seen from the following interview transcript.

$R \quad:$ Please, could you explain the method you use?

S4 : Sorry, sir, I wrote the wrong question, it should be $240^{\circ}$. I am not careful in writing what is known in the question, sir.

From the interview transcript above, it can be seen that the factor causing the subject to experience errors in facts is not being careful in writing down the information that is known in the problem.

$$
\begin{aligned}
& \text { (5) diketahui } 300^{\circ}=\frac{5}{3} \pi \text { radian dan } r=3,7 \\
& 5=r \theta \\
& 5=3,7\left(\frac{5}{3} \pi\right)=\frac{37}{6} \pi \\
& \begin{array}{r|r}
5=7 \theta \\
\frac{37}{6} \pi=7,1 \theta \\
\frac{37}{6} \pi \\
7,1
\end{array}\left\{\begin{array}{c}
\frac{37}{6} \pi \cdot \frac{10}{71}=\theta \\
\frac{185}{213} \pi=\theta \\
\theta=\frac{185}{213}\left(180^{\circ}\right)=156,33^{\circ}
\end{array}\right.
\end{aligned}
$$

Figure 6. Errors in Writing Information in the Problem

From the exposure of the research results, it was obtained a description of student errors in

\begin{tabular}{|c|c|c|c|}
\hline No & Types of Errors & Error Description & The Causes \\
\hline 1 & Misconception & $\begin{array}{l}\text { Misconceptions in solving the } \\
\text { problem of applying the radian } \\
\text { measurement are (1) } \\
\text { misunderstanding in applying the } \\
\text { equivalent ratio, (2) } \\
\text { misunderstanding the value of } \theta \\
\text { in the arc length formula } s=r \theta \text {, } \\
\text { and (3) misunderstanding in } \\
\text { using the ratio of the area of a } \\
\text { circle to the area of a section. }\end{array}$ & $\begin{array}{l}\text { The factors that cause each of these } \\
\text { misconceptions are: (1) directly using } \\
\text { the equivalent comparison, without } \\
\text { analyzing the type of comparison that } \\
\text { can be used to solve the problem, (2) } \\
\text { the misconception that the value of } \theta= \\
360^{0} \text {, and (3) the misunderstanding } \\
\text { that the area of a square can always be } \\
\text { compared with the area of a circle, this } \\
\text { is because every circle has the same } \\
\text { value of pi. }\end{array}$ \\
\hline 2 & Factual Error & $\begin{array}{l}\text { Factual error in solving the } \\
\text { problem of applying radian } \\
\text { measurements is errors in } \\
\text { rewriting the information } \\
\text { contained in the problem. }\end{array}$ & $\begin{array}{l}\text { The factor causing this factual error is } \\
\text { not being careful in writing down the } \\
\text { information that is known in the } \\
\text { problem. }\end{array}$ \\
\hline
\end{tabular}
solving the radian measurement problem along with the factors causing it, which can be seen in Table 3.

Table 3. Description of Student Errors in Solving Radian Measurement Problems 
The results of this research contribute to developing theories about errors in solving mathematical problems of applying the radian measurements. The results showed that the errors of the first semester students in solving the problem of applying the radian measurement consisted of misconception and factual errors. The results of this research are in accordance with the results of previous researches which showed that students experienced misconceptions and also errors in facts in solving trigonometry problems (Gür, 2009; Hidayat \& Aripin, 2020; Imelda, 2018; Jaelani, 2017; Nabie et al., 2018; Setiawan, 2021c, 2021a, 2021b, 2021d). However, the results of this research extend the results of previous researches by explaining the errors of prospective teachers in the material for applying radian measurements.

The first error is a misconception. Misconceptions that arise in this research are errors in using comparisons of components or elements in a circle to determine the size of the central angle and errors in understanding the value of angle from the arc length formula $s=r \theta$. The main cause of this misconception is intuitive thinking, namely thinking that is only based on perception without further analysis. The results of the research show that the material in this trigonometry course performs more analysis. In addition, (Nabie et al., 2018), someone who has research results expands the results of previous research by explaining analytical thinking in solving problems of applying radian measurements. The analytical thinking needed in solving this problem is to find the elements or components in the circle that are related to one another and analyze them logically, whether the comparison between the elements or components in the circle is an equivalent comparison or reverse value.

The second error is a factual error. This factual error is an error in rewriting the information contained in the problem. The main cause of this error is not being careful in paying attention to the information in the problem. The results of the research indicate that accuracy is needed by a student to succeed in solving math problems (Byers, 2009; Setiawan, 2020d; Setiawan et al., 2020). The results also show that students can correct their mistakes in solving problems so that they get the right answer (Setiawan, 2020a, 2020d, 2020e). Even this accuracy is a component of thinking disposition that must be possessed by a student, to be more productive in solving problems (Setiawan et al., 2020). Therefore, before starting to solve the problem, a student must first check whether the information in the question has been written correctly.

The implication of the results of this research is to reduce misconceptions and factual errors in learning trigonometry in problem-solving materials for the application of radian measurements. The first implication is to reduce misconceptions. The factor causing the first misconception is intuitive thinking which directly applies comparisons without analyzing the elements or components in interrelated circles. Therefore, the cause of this error needs to be reduced by asking students to identify the elements in the circle that are interrelated. For example, the interrelated circle elements used to solve the problem in Figure 2 include: The arc length of the small circle is the same as the arc length of the large circle. Because the two circles coincide with each other, and when they rotate, the length of the rotating arc is the same; The linear speed of rotation of the small circle is the same as the linear speed of rotation of the large circle. Since the two circles coincide, the linear velocity is the same; The angle at the center of a small circle is inversely proportional to the angle in a large circle (the larger the radius of the circle, the smaller the central angle, and vice versa). This is because the two circles have different radii lengths and the two circles coincide. In addition, it is important to identify elements that are not related to the question asked. For example, the area of a circle has no relation to the size of the central angle in the context of the problem in Figure 2 (possibly in other contexts it has a relationship). Therefore, it is important to identify the interrelated and unrelated elements of the 
circle. Thus, this concept error can be reduced. The second factor causing the misconception is a misunderstanding of the arc length formula $s=r \theta$. This misunderstanding is resolved by providing an explanation and understanding that the $\theta$ value is the central angle formed by the cross. If the length of the arc in question is the circumference of a circle, then the value of $\theta=$ $2 \pi$. Thus, it is expected that this misconception can be overcome.

The second implication is learning to reduce factual errors. This factual error arises because of the lack of accuracy in identifying the information contained in the question. Therefore, lecturers or teachers should emphasize to students or students to re-examine the information in the question. Then start solving the problem. This means, in addition to correcting the process and results of solving problems, accuracy is also important to re-check the written information with the information in the problem. The results of the research indicate that a lack of attention to the information contained in the question can lead to errors (Becker \& Rivera, 2005). Thus, factual errors in the form of errors in identifying the information contained in the question can be reduced.

Based on the results of the research and the discussion, it is found that the importance of the results of this research is used for solutions in overcoming misunderstandings in concepts and errors in facts in teaching the material for applying radian measurements. The solution to the misunderstanding in solving the problem of applying the radian measurements can be seen in Table 4. Table 4 shows that the most common misconceptions about concepts are caused by intuitive thinking and not doing analytical thinking on interrelated elements. Therefore, analytical thinking is needed to succeed in learning trigonometry material.

Table 4. Description of Student Errors and Solutions

\begin{tabular}{llll}
\hline No & Types of Errors & \multicolumn{1}{c}{ Error Description } & \multicolumn{1}{c}{ Solution } \\
\hline 1 & Misconception & $\begin{array}{l}\text { Misunderstanding in applying } \\
\text { the equivalent ratio. }\end{array}$ & $\begin{array}{l}\text { Analyze the appropriate type of } \\
\text { comparison to solve the problem } \\
\text { of applying the radian } \\
\text { measurements. } \\
\text { The value of } \theta \text { is not } 360^{\circ}, \\
\text { where the value of } \theta \text { is the }\end{array}$ \\
& $\begin{array}{l}\text { Misunderstanding the value } \\
\text { of } \theta \text { in the arc length formula } \\
\mathrm{s}=\mathrm{r} \theta\end{array}$ & $\begin{array}{l}\text { measure of the central angle } \\
\text { formed by the section. }\end{array}$ \\
& $\begin{array}{l}\text { Misunderstanding in using the } \\
\text { ratio of the area of a circle to } \\
\text { the area of a section. }\end{array}$ & $\begin{array}{l}\text { Perform an analysis of the } \\
\text { elements of a circle that have a } \\
\text { relationship. } \\
\text { Error in writing the } \\
\text { information in the question. }\end{array}$ & $\begin{array}{l}\text { The evaluation of what was } \\
\text { written and the procedure for } \\
\text { solving it. }\end{array}$ \\
& &
\end{tabular}

\section{CONCLUSIONS}

From the results of the research, it can be concluded that the errors of the prospective teachers in solving the problem of applying quadrant measurements consist of misconception and factual errors. This misconception is in the form of a misunderstanding in comparing the elements or components of a circle used to determine the central angle and a misunderstanding of the value of $\theta$ in the arc length formula $s=r \theta$. This misconception is caused by thinking that is only based on perception, without analyzing the problem. Factual errors in this research are in the form of errors in paying attention to the information contained in the question due to a lack of accuracy in identifying the information known in the question. 
Although this research is limited to 4 subjects, this research contributes to developing the theory of misconception and factual errors in the material for applying the radian measurements. Therefore, the researchers recommend conducting further analysis of the errors of students in solving trigonometry problems in various trigonometric materials. This research will be useful in uncovering students' misconceptions that can be used to improve students' understanding and improve the learning. The researchers also recommend the teacher or lecturer analyze the elements of a circle that are interconnected in solving the problem of applying the radian measurements. In addition, the researchers also recommend the teacher or lecturer emphasize the importance of accuracy in writing the information that is known in the problem because it can reduce factual errors.

\section{AUTHOR CONTRIBUTIONS STATEMENT}

YES participated in writing the original draft as well as conceptualization, while SS participated in methods, data curation, validation. for editing done with all authors.

\section{REFERENCES}

Baroody, A. J., Feil, Y., \& Johnson, A. R. (2007). An alternative reconceptualization of procedural and conceptual knowledge. Journal for Research in Mathematics Education, $38(2), 115-131$.

Becker, J. R., \& Rivera, F. (2005). Generalization strategies of beginning high school algebra students. International Group for the Psychology of Mathematics Education, 4, 121-128.

Becker, J. R., \& Rivera, F. D. (2007). Factors affecting sevent graders' cognitive perceptions of patterns involving constructive and deconstructive generalizations. In J. H. Woo, H. C. Lew, $\&$ D. Y. Seo (Eds.), Proceedings of the 31st Conference of the International Group for the Psychology of Mathematics Education (Vol. 4, pp. 129-136). PME.

Byers, T. (2009). The basic intervention mathematics program for at-risk students. Australian Mathematics Teacher, 65(1), 6-11.

Christinove, R. M., \& Mampouw, H. L. (2019). A review of solo taxonomy on students' errors in high mathematical abilities in calculating definite integral of trigonometric functions. $A l$ Jabar: Jurnal Pendidikan Matematika, 10(1), 11-20. https://doi.org/10.24042/ajpm.v10i1.3858

Gür, H. (2009). Trigonometry learning. New Horizons in Education, 57(1), 67-80.

Hidayat, W., \& Aripin, U. (2020). Identifikasi kesalahan jawaban mahasiswa pada mata kuliah trigonometri berdasarkan dimensi pengetahuan krathwohl. Jurnal Nasional Pendidikan Matematika, 4(1), 142-153.

Imelda. (2018). Analisis kesulitan mahasiswa dalam menyelesaikan soal pemecahan masalah pada mata kuliah aljabar dan trigonometri. Journal of Mathematics Education and Science, $4(1), 49-56$.

Jaelani, A. (2017). Kesalahan jawaban tes trigonometri mahasiswa pendidikan matematika semester pertama. Journal of Mathematics Education, 3(2), 1-13.

Lial, M. L., Hornsby, J., Schneider, D. I., \& Daniels, C. J. (2016). Trigonometry (11th ed.). Pearson. 
Muthukrishnan, P., Kee, M. S., \& Sidhu, G. K. (2019). Addition error patterns among the preschool children. International Journal of Instruction, 12(2), 115-132. https://doi.org/10.29333/iji.2019.1228a

Nabie, M. J., Akayuure, P., Ibrahim-Bariham, U. A., \& Sofo, S. (2018). Trigonometric concepts: Pre-service teachers' perceptions and knowledge. Journal on Mathematics Education, 9(2), 169-182. https://doi.org/10.22342/jme.9.2.5261.169-182

Nejad, M. J. (2016). Undergraduate students' perception of transformation of sinusoidal functions. In M. B. Wood, E. E. Turner, M. Civil, \& J. A. Eli (Eds.), Proceedings of the 38th annual meeting of the North American Chapter of the International Group for the Psychology of Mathematics Education (pp. 589-596). The University of Arizona.

Oktaviani, M. (2017). Analysis of students' error in doing mathematics problem on proportion. Proceedings Ofthe 2nd Asian Education Symposium (AES 2017), March, 172-177. https://doi.org/10.5220/0007300601720177

Safriani, W., Munzir, S., Duskri, M., \& Maulidi, I. (2019). Analysis of students' errors on the fraction calculation operations problem. Al-Jabar : Jurnal Pendidikan Matematika, 10(2), 307-318. https://doi.org/10.24042/ajpm.v10i2.5224

Schleppenbach, M., Flevares, L. M., \& Sims, L. M. (2007). Teachers' responses to student mistakes in chinese and u.s. mathematics classrooms. The Elementary School Journal, 108(2), 131-147.

Setiawan, Y. E. (2020a). Analisis kemampuan siswa dalam pembuktian kesebangunan dua segitiga. Al-Khwarizmi: Jurnal Pendidikan Matematika Dan Ilmu Pengetahuan Alam, 8(1), 25-40. https://dx.doi.org/10.24256/jpmipa.v8i1.800

Setiawan, Y. E. (2020b). Analisis kesalahan siswa dalam menggeneralisasi pola linier. Jurnal Nasional Pendidikan Matematika, 4(2), 180-194. https://dx.doi.org/10.33603/jnpm.v4i2.3386

Setiawan, Y. E. (2020c). Analisis kesalahan siswa dalam menilai kebenaran suatu pernyataan. Jurnal Didaktik Matematika, 7(1), 13-31. https://doi.org/10.24815/jdm.v7i1.14495

Setiawan, Y. E. (2020d). Proses berpikir siswa dalam memperbaiki kesalahan generalisasi pola linier. Mosharafa: Jurnal Pendidikan Matematika, 9(3), 371-382. https://doi.org/10.31980/mosharafa.v9i3.751

Setiawan, Y. E. (2020e). The thinking process of students using trial and error strategies in generalizing linear patterns. Numerical: Jurnal Matematika Dan Pendidikan Matematika, 4(1), 1-12. https://doi.org/10.25217/numerical.v4i1.839

Setiawan, Y. E. (2021a). Analisis kesalahan mahasiswa semester pertama dalam menentukan nilai fungsi trigonometri sudut istimewa. Supremum Journal of Mathematics Education, 5(1), 110-121. https://doi.org/10.35706/sjme.v5i1.4531

Setiawan, Y. E. (2021b). Analisis kesalahan mahasiswa semester pertama dalam menentukan nilai fungsi trigonometri sudut kuadran. Jurnal Cendekia: Jurnal Pendidikan Matematika, 5(1), 321-334. https://doi.org/10.31004/cendekia.v5i1.413

Setiawan, Y. E. (2021c). Identifikasi kesalahan mahasiswa dalam menyelesaikan masalah matematika (studi kasus masalah segitiga pada mata kuliah trigonometri). Jurnal Kependidikan: Jurnal Hasil Penelitian Dan Kajian Kepustakaan Di Bidang Pendidikan, Pengajaran Dan Pembelajaran, 7(3), 649-662. https://doi.org/10.33394/jk.v7i3.3329 
Setiawan, Y. E. (2021d). Kesalahan mahasiswa semester pertama dalam menyelesaikan masalah fungsi trigonometri sudut tidak lancip. Aksioma: Jurnal Program Studi Pendidikan Matematika, 10(2), 599-614. https://doi.org/10.24127/ajpm.v10i2.3458

Setiawan, Y. E. (2021e). Kesalahan mahasiswa semester pertama dalam menyelesaikan masalah kecepatan sudut pada mata kuliah trigonometri. Pythagoras: Jurnal Pendidikan Matematika, 16(1), 19-32. https://doi.org/10.21831/pg.v16i1.38560

Setiawan, Y. E., Purwanto, Parta, I. N., \& Sisworo. (2020). Generalization strategy of linear patterns from field-dependent cognitive style. Journal on Mathematics Education, 11(1), 77-94. https://doi.org/10.22342/jme.11.1.9134.77-94

Siyepu, S. W. (2015). Analysis of errors in derivatives of trigonometric functions. International Journal of STEM Education, 2(1), 1-16. https://doi.org/10.1186/s40594-015-0029-5

Tuna, A. (2013a). A conceptual analysis of the knowledge of prospective mathematics teachers about degree and radian. Word Journal of Education, 3(4), 1-9. https://doi.org/10.5430/wje.v3n4p1

Tuna, A. (2013b). The influence of the 5E model on the elimination of misconceptions on the subject of trigonometry. International Journal of Academic Research, 5(3), 14-21. https://doi.org/10.7813/2075-4124.2013/5-3/a.3 
Setiawan, Y. E., \& Surahmat, S 